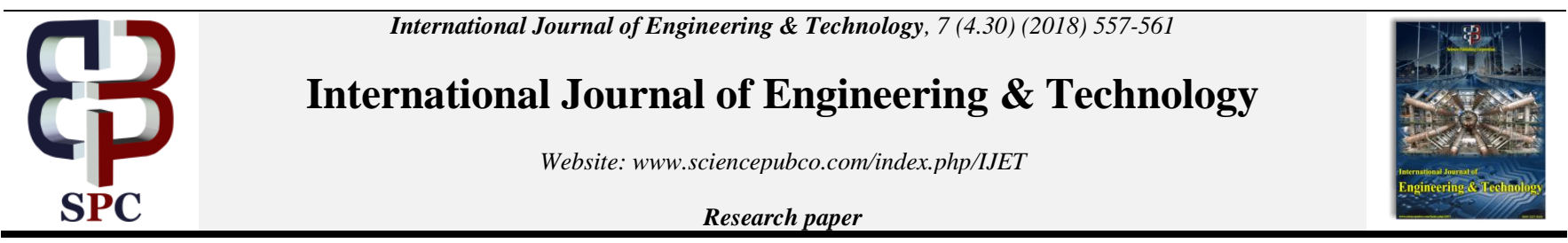

\title{
Investigation of $\mathrm{PO}_{4}{ }^{3-}$ Removal in Aerated and Unaerated High Fe EAF-Slag Filter System
}

\author{
Hamdan, R*1, Siti Zu Nurain Ahmad², Nur 'Ain Nazirah Mohd Arshad³, Wan Afnizan Wan Mohamed ${ }^{4}$, Syahrul \\ Nizam Maarup 5 \\ ${ }^{1,3,4,5}$ Faculty of Civil Engineering and Environmental, Universiti Tun Hussein Onn Malaysia, 86400 Parit Raja, Batu Pahat, Johor, \\ Malaysia \\ 2. Department of Civil Engineering Technology, Faculty of Engineering Technology, Universiti Tun Hussein Onn Malaysia, 86400 Parit \\ Raja, Batu Pahat, Johor, Malaysia \\ *Corresponding author E-mail: rafidahh@edu.my
}

\begin{abstract}
Phosphorus in wastewater is one the main culprit which accelerates eutrophication in waterbody if it is not being treated properly. Steel slag filter emerged as one alternative treatment for wastewater. However, the variousness of metal oxides including Fe in steel slag will affect the phosphorus removal efficiency. Thus, this study was conducted to investigate the ability of a series of lab-scale high Fe electric arc furnace (EAF- slag) column filters in removing PO43- from synthetic wastewater. The systems were operated under aerated and unaerated within acidic and alkaline conditions. Synthetic wastewater contained $25 \mathrm{mg} / \mathrm{L}$ was prepared as the feed and monitored weekly basis for the $\mathrm{PO}_{4}{ }^{3-}$ removal efficiency and the total metals $(\mathrm{Ca}, \mathrm{Fe}$, and $\mathrm{Mg}$ ) concentrations in the effluents. The results show that both aerated and unaerated high Fe EAF-slag filter systems have high $\mathrm{PO}_{4}{ }^{3-}$ removal efficiency under acidic condition, which unaerated system performed slightly better. It can be observed that unaerated systems performed better in removing $\mathrm{PO}_{4}{ }^{3-}$ at acidic and neutral $\mathrm{pH}$ values but not at extremely high $\mathrm{pH}$. As for the $\mathrm{PO}_{4}{ }^{3-}$ removal mechanism was achieved by adsorption and precipitation at acidic $\mathrm{pH}$ and the concentration of $\mathrm{Ca}, \mathrm{Mg}$ and $\mathrm{Fe}$ in effluents was related to the $\mathrm{PO}_{4}{ }^{3-}$ removal efficiency at different $\mathrm{pH}$ values.
\end{abstract}

Keywords: Adsorption, PO43- removal; adsorption; electric arc furnace slag; $\mathrm{pH}$; rock filters.

\section{Introduction}

Phosphorus is a culprit nutrient in accelerating of eutrophication in natural surface waters. Eutrophication occurs when the aquatic ecosystem gets over-enrichment with a nutrient that comes from construction sites, runoff agricultural, urban areas and it is lead to algal bloom and anoxic events that exist constantly at the surface of the water. Acceleration of algae growth will eventually will cause eutrophication in aquatic ecosystem [1]. Therefore, removal of phosphorus in wastewater has become among the important issue and indicator of determining the efficiency and reliability of the treatment system of the wastewater.

Wastewater must undergo conventional and advanced treatment prior to be discharged to river. However, the need of alternative treatment is emerged due to chemical cost and complexity. Therefore, the development of low cost technology for wastewater treatment including steel slag filter is become popular. Steel slag, a by-product from steel manufacturing industry filter is amongst a high potential medium for removing phosphate from wastewater as it contains high concentrations of metal oxides including $\mathrm{Ca}$, $\mathrm{Fe}, \mathrm{Al}$ and $\mathrm{Mg}$ [2].

The removal mechanisms of $\mathrm{PO}_{4}{ }^{3-}$ is either through adsorption or precipitation depends on the existing of metal oxides concentrations [3]. Therefore, it may due to chemical compositions of steel slag. This variousness are due to the disparity in the grade of steel products and type of furnaces used during the process of steelmaking[4].

Furthermore, performance of phosphorus removal in aqueous system are affected due to several factors including $\mathrm{pH}$ and con- centration of metallic salts [5]. The influent's pH are one of the closely related with phosphorus removal. In general, phosphorus removal using steel slag system prefers basic condition where adsorption will occur at low $\mathrm{pH}$ and $\mathrm{Ca} \mathrm{PO}_{4}{ }^{3}$ will precipitate at high $\mathrm{pH}$ value. Insoluble phosphates in a steel slag filter system are chemically precipitated with ferric iron under aerobic conditions. For instance, $\mathrm{Ca}$ and $\mathrm{Al}$ in the form of clay particles, ferric and $\mathrm{Al}$ hydroxides and oxides tend to be adsorbed onto adsorbent surfaces [6]. Furthermore, some polyphosphate is hydrolysed to orthophosphate under aerobic conditions, which is a readily available nutrient and assimilates for the growth of bacteria and energy transfer. Then, orthophosphate is released as the $\mathrm{HPO}_{4}{ }^{2-}$ ion under this condition. In $\mathrm{Ca}^{2+}$ concentrated system, precipitations of orthophosphate as hydroxyapatite from the solution occur and incorporated subsequently into floc particles [7].

In this study, different composition of metal oxides in steel slag has been studied. When high percentage of $\mathrm{CaO}$ present in the steel slag in high $\mathrm{pH}$ value conditions, precipitation of $\mathrm{Ca} \mathrm{PO}_{4}{ }^{3-}$ is expected to be formed where it dominates the removal mechanism. On the other hand, when the steel slag contains high percentage of iron, adsorption into $\mathrm{Fe}$ oxides will dominate the $\mathrm{PO}_{4}{ }^{3-}$ removal mechanism at acidic and neutral $\mathrm{pH}$ range [8]. However, adsorption is not the only interaction which occurs between $\mathrm{Fe}$ oxides and ortho $\mathrm{PO}_{4}{ }^{3-}$. The dissolution of $\mathrm{Fe}^{3+}$ from $\mathrm{Fe}$ oxides will indicates that precipitation might occur [9]. $\mathrm{Fe}^{3+}$ ions are tend to dissolve in acidic condition which leads to the precipitation of $\mathrm{Fe} \mathrm{PO}_{4}{ }^{3-}$ meanwhile $\mathrm{Ca}^{2+}$ ions tend to dissolve in basic condition, which related to $\mathrm{Ca} \mathrm{PO}_{4}{ }^{3-}$ formation. 


\section{Experimental}

\subsection{Filter medium}

The EAF-slag was obtained from Antara Steel Mills Sdn. Bhd located at Pasir Gudang, Johor, Malaysia which consist of 38.3\% $\mathrm{Fe}_{2} \mathrm{O}_{3}, 20.4 \%$ of $\mathrm{CaO}, 15.2 \% \mathrm{SiO}_{2}, 7.0 \% \mathrm{Al}_{2} \mathrm{O}_{3}, \%, 5.19 \% \mathrm{MnO}$ and $3.22 \mathrm{MgO}$ has been used as a filter medium. The EAF-slag was characterized using X-ray Fluorescence Spectroscopy (XRF) for chemical composition determination. The EAF-slag was ground using Ball Mill grinder. The EAF-slag samples sizes range from $9.5 \mathrm{~mm}$ to $20 \mathrm{~mm}$. The samples were then washed twice and oven dried for 24 hours at drying temperature $100 \pm 5^{\circ} \mathrm{C}$.

\subsection{Column study}

Twelve sets of Lab-scale vertical high Fe EAF-slag filters was constructed to study the effectiveness of phosphorus removal system from synthetic wastewater. The filter systems were conducted in two conditions; aerated and unaerated. Column filters made from Perspex materials with the dimension of $400 \mathrm{~mm}$ total height, $150 \mathrm{~mm}$ inner diameter and $6 \mathrm{~mm}$ thickness. The $\mathrm{pH}$ values of influents were adjusted using $\mathrm{NaOH}$ and $\mathrm{H}_{2} \mathrm{SO}_{4}$ from acidic to alkaline and control for aerated and unaerated system as shown in Figure 1. Distilled water was used as feed for the control column filters.

The pH meter (HANNA HI-99310, UK) was used to monitor the $\mathrm{pH}$ value throughout the experiment to minimize the fluctuations. The synthetic wastewater was then prepared with $25 \mathrm{mg} \mathrm{PO}_{4}{ }^{3-} / \mathrm{L}$ (typical concentration of $\mathrm{PO}_{4}{ }^{3-}$ of domestic wastewater) by dissolving into distilled water and fed via gravity to the influent of each filter. The column filters were aerated by using compressed air. The aeration was controlled to provide tiny and uniform bubbles of air to spread evenly throughout the column filters. Wastewater sample from influents and effluents of each filter have been sampled and analysed on weekly basis for the selected parameters including $\mathrm{pH}$, ortho- $\mathrm{PO}_{4}{ }^{3-}$ concentration and metals including $\mathrm{Ca}, \mathrm{Fe}$, and $\mathrm{Mg}$ concentration.

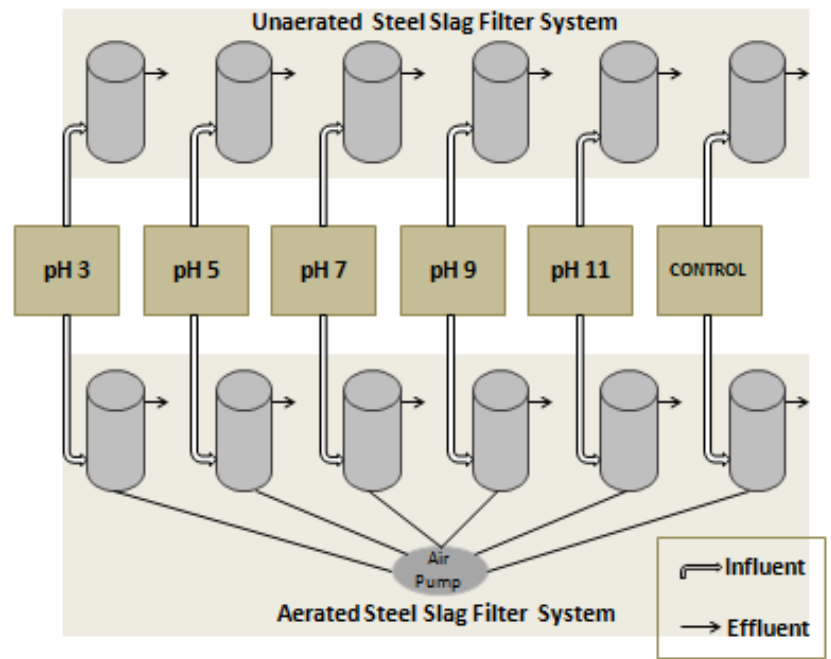

Fig. 1: Layout of the experimental setup

\subsection{Analysis of $\mathrm{PO}_{4}^{3-}$}

The concentration of orthoPO ${ }_{4}^{3-}$ was measured using ascorbic acid reduction method. The removal efficiency of removal of $\mathrm{PO}_{4}{ }^{3-}$ was obtained using the following equation:

Removal percentage $(\%)=\frac{\mathrm{C}_{0}-\mathrm{C}_{\mathrm{e}}}{\mathrm{C}_{0}} \times 100$ in which $\mathrm{C}_{0}$ is the initial ortho $\mathrm{PO}_{4}^{3-}$ concentration (influent) in $\mathrm{mg} / \mathrm{L}$ and $\mathrm{C}_{\mathrm{e}}$ is the final ortho $\mathrm{PO}_{4}{ }^{3-}$ concentration (effluent) in $\mathrm{mg} / \mathrm{L}$. Meanwhile, the metal concentration; $\mathrm{Ca}, \mathrm{Fe}$ and $\mathrm{Mg}$ were measured using atomic absorption spectrometric (AAS), (Perkin Elmer Analyst 100, US) method.

\section{Results and Discussion}

\subsection{High Fe EAF-slag filters Performance in removing $\mathrm{PO}_{4}{ }^{3-}$ at different $\mathrm{pH}$}

Figure 2 until Figure 6 shows the $\mathrm{PO}_{4}{ }^{3-}$ removal efficiency at different $\mathrm{pH}$ values EAF-slag filter systems. The $\mathrm{PO}_{4}{ }^{3-}$ removal efficiencies for unaerated and aerated $\mathrm{pH} 3$ systems were between 78 $89 \%$ and $76-85 \%$ respectively. They show the best $\mathrm{PO}_{4}{ }^{3-}$ removal efficiency for both systems. Meanwhile, the $\mathrm{PO}_{4}{ }^{3-}$ removal efficiency for unaerated $\mathrm{pH} 5$ system was $74-88 \%$ whereas for aerated system was $61-76 \%$. Both $\mathrm{pH} 5$ systems also exhibit good $\mathrm{PO}_{4}{ }^{3-}$ removal efficiency though they have slightly less performance compared to $\mathrm{pH} 3$ systems. Therefore, acidic $\mathrm{pH}$ EAF-slag filters have higher $\mathrm{PO}_{4}{ }^{3-}$ removal efficiency compared to neutral and alkaline $\mathrm{pH}$.

For unaerated and aerated $\mathrm{pH} 7$ systems, the $\mathrm{PO}_{4}{ }^{3-}$ removal efficiency was found to be $55-87 \%$ and $36-67 \%$ respectively. However, the first week's performance of unaerated $\mathrm{pH} 7$ system was considerably slow, around $37.9 \%$ only where aerated $\mathrm{pH} 7$ has shown good $\mathrm{PO}_{4}{ }^{3-}$ removal performance, $61.7 \%$. This contradiction at first week of the experiment compared to the rest of the weeks might be due to the vibration produced during aeration which causes reaction to proceed faster compared to without aeration (unaerated system). Eventually, the result started to follow the normal trend. On the other hand, for unaerated and aerated $\mathrm{pH} 9$ systems, their $\mathrm{PO}_{4}{ }^{3-}$ removal efficiencies were $51-71 \%$ and $25-55 \%$ respectively. It is clearly seen that unaerated system perform better at removing $\mathrm{PO}_{4}{ }^{3-}$ compared to aerated system.

Generally, for high Fe EAF-slag filters with $\mathrm{pH}$ values of 3, 5, 7, and 9 , they showed that the unaerated system provide higher $\mathrm{PO}_{4}{ }^{3-}$ removal efficiency compared to the aerated system. However, significant difference can be seen in the systems with $\mathrm{pH} 11$ where the $\mathrm{PO}_{4}{ }^{3-}$ removal efficiency for aerated system is higher, 24-64\% compared to the unaerated systems, around $21-41 \%$. Only at extremely high $\mathrm{pH}(\mathrm{pH} 11)$, aerated system surpass the performance of unaerated system. The $\mathrm{PO}_{4}{ }^{3-}$ removal efficiency of EAF-slag at acidic $\mathrm{pH}$ influent is higher compared to the influents of neutral and alkaline $\mathrm{pH}$. These results are similar and following Han et al. [8] and Xue et al., [10]. The difference in $\mathrm{PO}_{4}{ }^{3-}$ removal efficiency can be related to the difference in the composition metal oxide of the EAF-slag used.

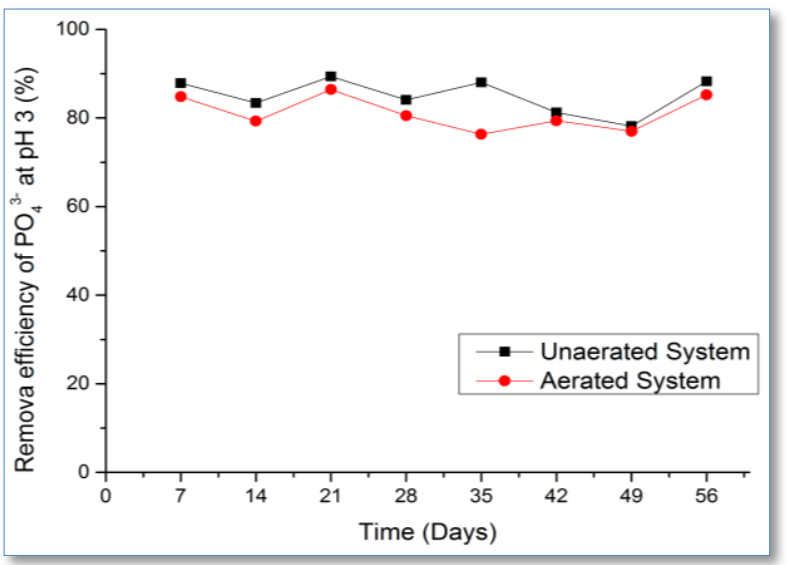

Fig. 2: Removal efficiency of $\mathrm{PO}_{4}{ }^{3-}$ at $\mathrm{pH} 3$ 


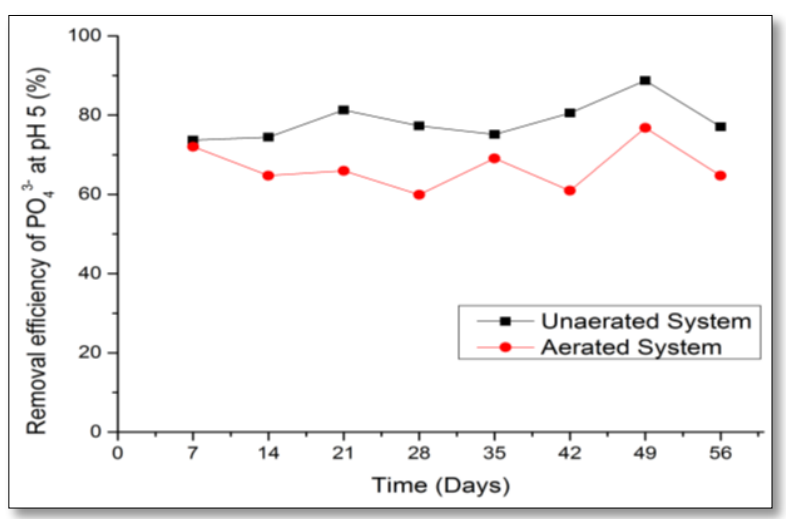

Fig. 3: Removal efficiency of $\mathrm{PO}_{4}{ }^{3-}$ at $\mathrm{pH} 5$

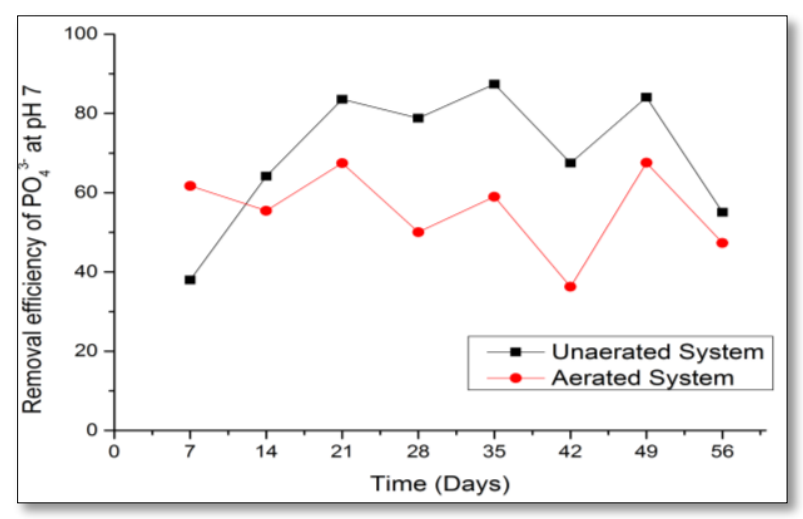

Fig. 4: Removal efficiency of $\mathrm{PO}_{4}{ }^{3-}$ at $\mathrm{pH} 7$

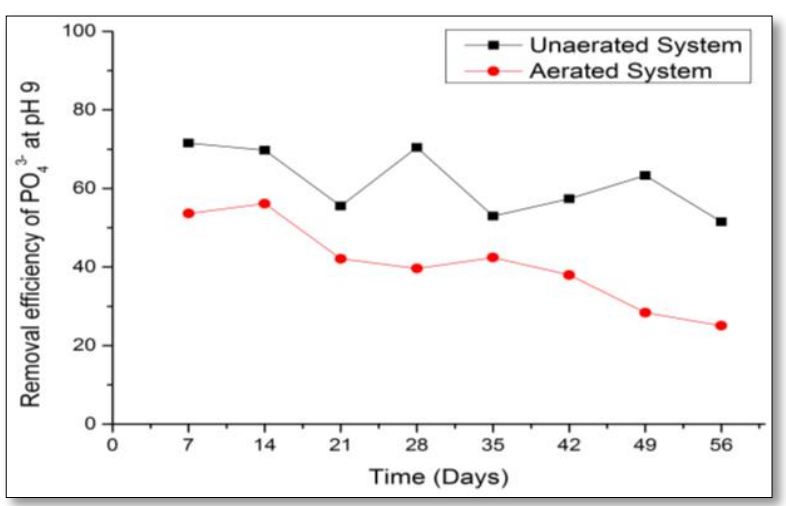

Fig. 5: Removal efficiency of $\mathrm{PO}_{4}{ }^{3-}$ at $\mathrm{pH} 9$

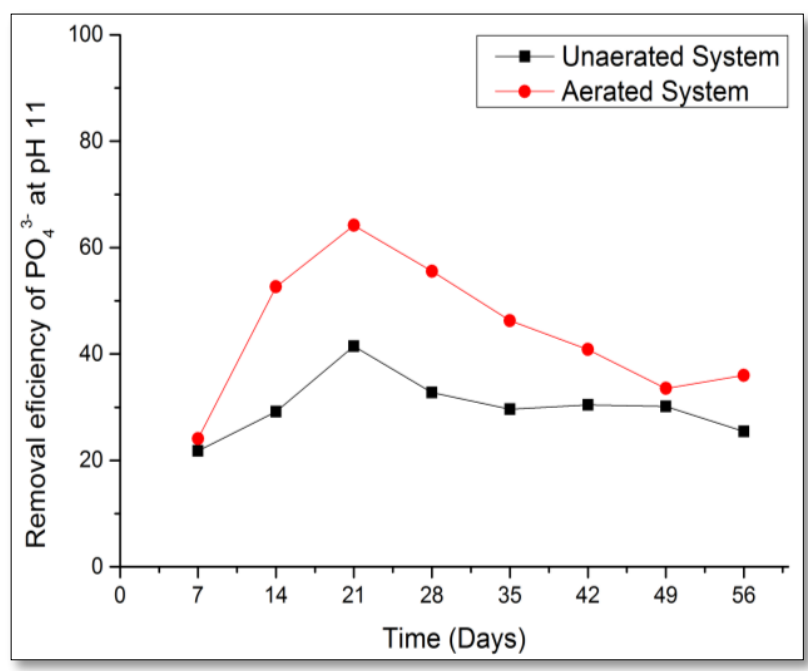

Fig. 6: Removal efficiency of $\mathrm{PO}_{4}{ }^{3-}$ at $\mathrm{pH} 11$

\subsection{The concentration of $\mathrm{Ca}^{2+}, \mathrm{Mg}^{2+}$ and $\mathrm{Fe}^{2+}$ in efflu- ents}

The Figure 7 shows the $\mathrm{Ca}^{2+}$ and $\mathrm{Mg}^{2+}$ ions concentration in effluents at the control column filters. It can be seen that both $\mathrm{Ca}^{2+}$ and $\mathrm{Mg}^{2+}$ ions concentration in aerated systems are higher compared to the unaerated systems. The concentrations of $\mathrm{Ca}^{2+}$ ions for aerated and unaerated Control systems are $21.7-28.9 \%$ and 12.823.2\%. Meanwhile, the concentrations of $\mathrm{Mg}^{2+}$ for aerated and unaerated Control systems are 1.1-3.5\% and 0.01-0.2.5 respectively. $\mathrm{Ca}^{2+}$ concentration is significantly high in the effluents compared to the Mg. This is match with the chemical compositions of EAF-slag which is significantly higher in $\mathrm{Ca}^{2+}$ compared to $\mathrm{Mg}^{2+}$.

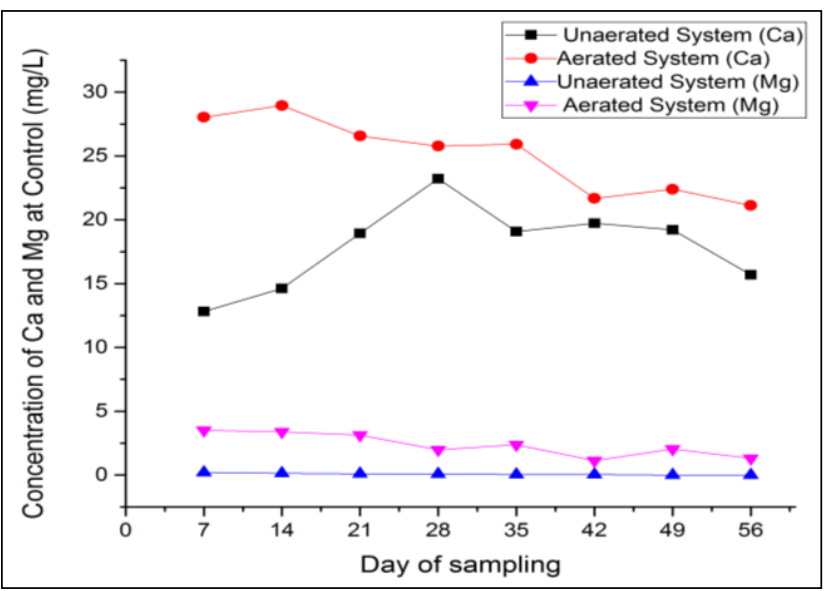

Fig. 7: Concentration of $\mathrm{Ca}$ and $\mathrm{Mg}$ at Control

Figure 8 shows the $\mathrm{Ca}^{2+}$ and $\mathrm{Mg}^{2+}$ concentrations of at $\mathrm{pH} 3$ for unaerated and aerated systems. Following similar trend of Control systems, the concentrations of $\mathrm{Ca}^{2+}$ and $\mathrm{Mg}^{2+}$ at $\mathrm{pH} 3$ were higher at aerated systems compared to unaerated systems. The concentrations of $\mathrm{Ca}^{2+}$ for aerated and unaerated at $\mathrm{pH} 3$ systems were 16.5 $40 \%$ and $14.6-26.2 \%$ respectively. On the other hand, the concentrations of $\mathrm{Mg}^{2+}$ for aerated and unaerated systems at $\mathrm{pH} 3$ were $1.7-5.2 \%$. These values are lower compared to the concentrations of $\mathrm{Ca}^{2+}$. Comparing the results obtained with control systems; $\mathrm{pH}$ 3 systems produce higher concentrations of $\mathrm{Ca}^{2+}$ and $\mathrm{Mg}^{2+}$ in the effluents. Thus, this shows that the nature of EAF-slag filters, when in contact with aqueous solution (aqueous solution in this experiment is distilled water), then the chemical components of the EAF-slag, mainly metal oxides, might leach out from the EAF-slag itself and come in contact with the wastewater.

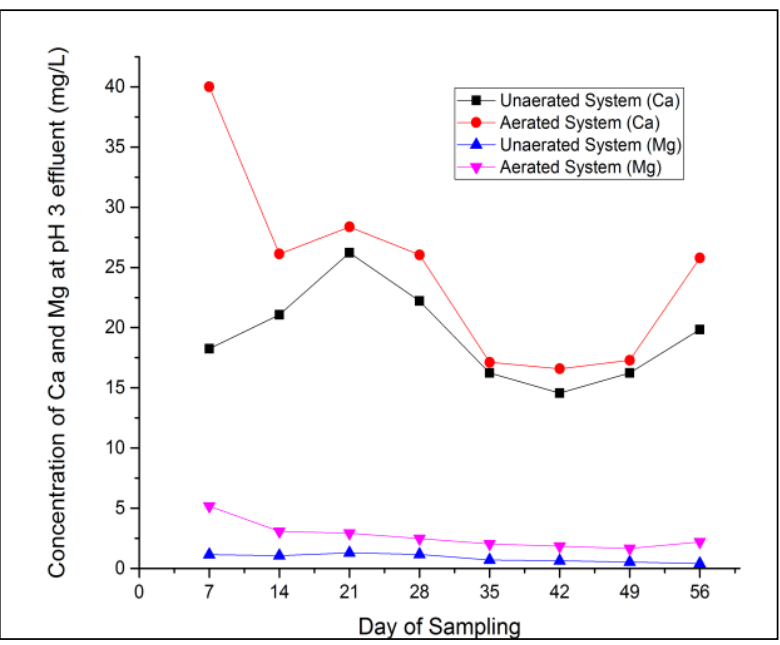

Fig. 8: Removal efficiency of $\mathrm{PO}_{4}{ }^{3-}$ at $\mathrm{pH} 3$

The concentrations of $\mathrm{Ca}^{2+}$ and $\mathrm{Mg}^{2+}$ at $\mathrm{pH} 5$ for unaerated and aerated systems were plotted in Figure 9. Aerated system contains 
higher $\mathrm{Ca}^{2+}$ and $\mathrm{Mg}^{2+}(9.9-20 \%$ and $1.6-3.1 \%$ respectively) compared to unaerated systems $(3.7-8.1 \%)$.

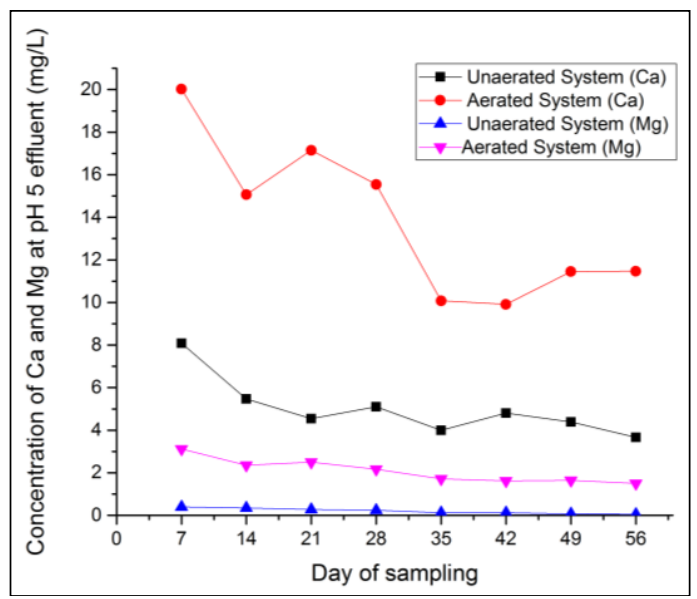

Fig. 9: Effluent concentration for both EAF-slag system at $\mathrm{pH} 5$

In Figure 10, the concentrations of $\mathrm{Ca}^{2+}$ and $\mathrm{Mg}^{2+}$ at $\mathrm{pH} 7$ were plotted. Similar trends as at $\mathrm{pH} 5$ can be seen and shown by $\mathrm{pH} 7$, 9 and 11 filters following trends shown by Control and $\mathrm{pH} 3$ filters. The concentrations of $\mathrm{Ca}^{2+}$ for aerated systems are significantly higher compared to the concentrations of another three parameters. Figure 11 and 12 shows the concentration of $\mathrm{Ca}^{2+}$ and $\mathrm{Mg}^{2+}$ at $\mathrm{pH} 9$ and $\mathrm{pH} 11$ respectively. It is known that the $\mathrm{PO}_{4}^{3-}$ removal for Ca-rich materials are through the calcium $\mathrm{PO}_{4}{ }^{3-}$ precipitation [11]. The role of $\mathrm{Ca}^{2+}$ released has been seen performing well in previous studies [12]. Therefore, the increase in $\mathrm{Ca}^{2+}$ in slag due to dissolution process can increase the concentrations of $\mathrm{Ca}^{2+}$ and $\mathrm{OH}^{-}$ions [8].

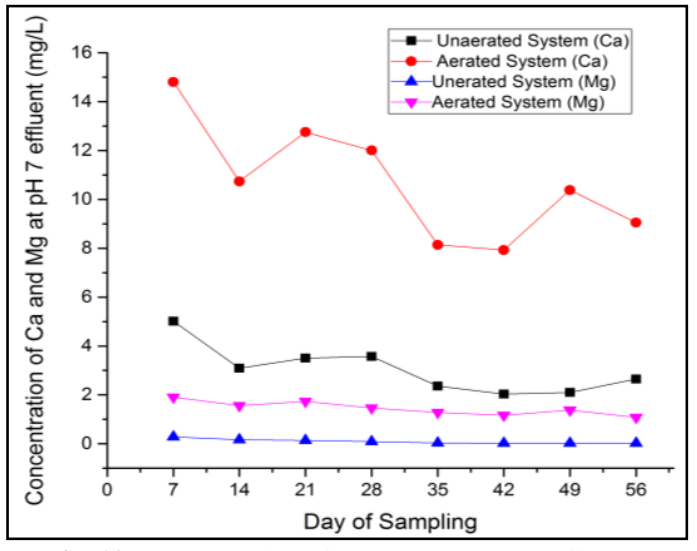

Fig. 10: Concentration of $\mathrm{Ca}$ and $\mathrm{mg}$ at $\mathrm{pH} 7$ effluents

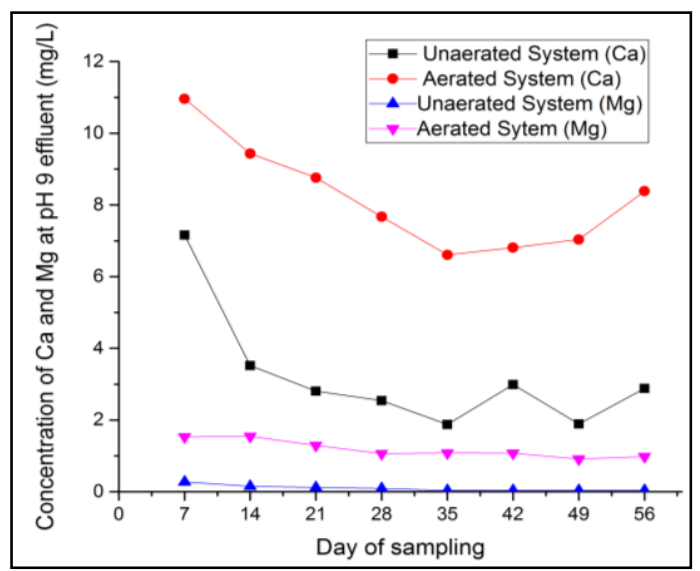

Fig. 11: Effluent concentration for both EAF-slag system at $\mathrm{pH} 9$

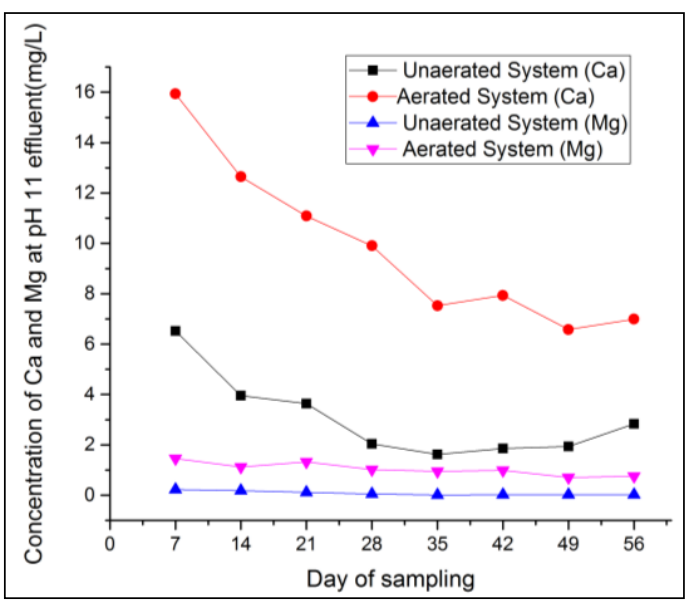

Fig. 12: Effluent concentration for both EAF-slag system at pH 11

The concentrations of $\mathrm{Fe}^{3+}$ in the effluents were illustrated in Figure 13. Only in a few column filters can be obtained the presence of $\mathrm{Fe}^{3+}$ in the effluents. Some of the unaerated systems contain $\mathrm{Fe}^{3+}$ which is filters of $\mathrm{pH} 3,5,7$, and 9. Meanwhile, for aerated systems, only aerated $\mathrm{pH} 3$ systems contains $\mathrm{Fe}$ in the effluents. Though the compositions of the EAF-slag used have highest percentage of $\mathrm{Fe}_{2} \mathrm{O}_{3}(38.2 \%)$, however the concentrations of $\mathrm{Fe}$ in the effluents did not reflects the highest percentage of $\mathrm{Fe}_{2} \mathrm{O}_{3}$. The high concentrations of $\mathrm{Fe}$ at $\mathrm{pH} 3$ systems are the results of dissolution of $\mathrm{Fe}^{3+}$ at acidic $\mathrm{pH}$ [8]. This suggests that very small amount of Fe ions leach out of the slag thus can be related to the adsorption process for the $\mathrm{PO}_{4}{ }^{3-}$ removal mechanism. Adsorption of $\mathrm{PO}_{4}{ }^{3-} \mathrm{Fe}$ oxides follows the inner-sphere ligand exchange mechanism [13] where they can react by forming bidentate or monodentate complexes depending on how they were coordinated [14][15]. However, red-brown colour sludge was also formed inside the filters which were pointed as precipitates of iron $\mathrm{PO}_{4}{ }^{3-} \mathrm{s}$. This suggested that the $\mathrm{PO}_{4}{ }^{3-}$ removal mechanism were following the precipitation process by forming precipitates with $\mathrm{Fe}$ ions from the steel slag apart from adsorption mechanism which happened simultaneously. Surface complexation (adsorption) tends to dominate the mechanism at low surface coverage, however, when the surface loading increase, precipitation becomes dominant [9].

Meanwhile, the concentrations of $\mathrm{Ca}^{2+}, \mathrm{Mg}^{2+}$ and $\mathrm{Fe}^{2+}$ at alkaline $\mathrm{pH}$ were significantly less compared to acidic $\mathrm{pH}$. At higher alkaline $\mathrm{pH}$, more hydroxide ions adsorbed onto slag surface which causes stronger repulsive and competitive adsorption [8] thus reduce sites for $\mathrm{PO}_{4}{ }^{3-}$ adsorption. Therefore, $\mathrm{PO}_{4}{ }^{3-}$ removal efficiency at higher alkaline $\mathrm{pH}$ decrease compared to acidic $\mathrm{pH}$. Acidic system contained higher concentration of $\mathrm{Ca}$ and $\mathrm{Fe}$ ions therefore they were better at removing $\mathrm{PO}_{4}{ }^{3-}$ compared to basic $\mathrm{pH}$.

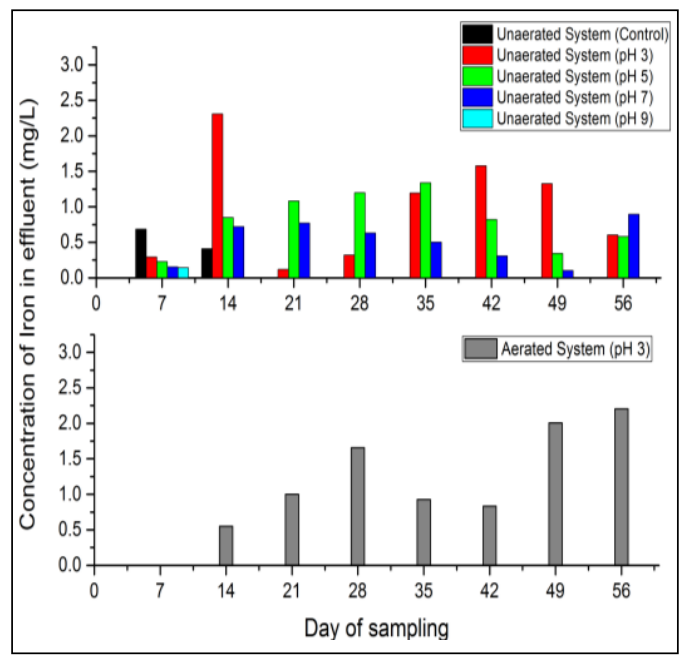

Fig. 13: Concentration of Fe in effluents 


\section{Conclusion}

This study concluded that the high Fe unaerated EAF-slag filters system has higher $\mathrm{PO}_{4}{ }^{3-}$ removal efficiency compared to aerated high Fe EAF-slag filters system with the exception of system at $\mathrm{pH}$ 11. The highest $\mathrm{PO}_{4}{ }^{3-}$ removal efficiency can be seen at acidic $\mathrm{pH}$ values. $\mathrm{Ca}^{2+}, \mathrm{Mg}^{2+}$ and $\mathrm{Fe}^{2+}$ concentrations in effluents also increase with the decrease in $\mathrm{pH}$ values though aeration causes higher concentration of $\mathrm{Ca}^{2+}, \mathrm{Mg}^{2+}$ and $\mathrm{Fe}^{2+}$ in the effluents.

\section{Acknowledgement}

We would like to thanked our funder: Ministry of Higher Education under Fundamental Research Crant Scheme (Vot 1613) and Universiti Tun Hussein Onn Malaysia.

\section{References}

[1] Ansari, A. A., \& Gill, S. S. (2014) Eutrophication: Causes, consequences and control: Volume 2. 1-262.

[2] Johansson-Westholm, L. 2006. Substrates for Phosphorus Removal-potential Benefits for On-site Wastewater Treatement?. Water Resources. 40: 23-36.

[3] Barca, C., Meyer, D., Liira, M., Drissen, P., Coemau, Y., Andres, Y., Chazarenc, F. 2014. Steel Slag Filters to Upgrade Phosphorus Removal in Wastewater Treatment Plants: Removal Mechanisms and Performance. Ecological Engineering. 68: 214-222.

[4] Barca, C., Troesch, S., Meyer, D., Drissen, P., Andres, Y., Chazarenc, F. 2013. Steel Slag Filters to Upgrade Phosphorus Removal in Constructed Wetlands: Two Years of Field Experiments. Environmental Science Technology. 47: 549-556.

[5] Hamdan, R., Mara, D. 2013. Study of In-filter Phosphorus Removal Mechanisms in an Aerated Blast Furnace Slag. International Journal of Research in Engineering and Technology. 2(8); 130-136.

[6] Scholz, M. (2006). Wetland systems to control urban runoff. Elsevier, Oxford,UK

[7] Gerardi, M.H. (2006). Wastewater bacteria. John Wiley and Sons, Inc., New York.

[8] Han, C., Wang, Z., Yang, W., Wu, Q., Yang, H., Xue, X. 2016. Effects of $\mathrm{pH}$ on Phosphorus Removal Capacities of Basic Oxygen Furnace Slag. Ecological Engineering. 89:1-6.

[9] Wifert, P., Kumar, P. S., Korving, L., Witkamp, G., Loosdrecht, M.C.M. 2015. The Relevance of Phosphorus and Iron Chemistry to the Recovery of Phosphorus from Wastewater: A Review. Environmental Science and Technology. 49: 99400-9414.

[10] Xue, Y., Hou, H., Zhu, S. 2009. Characteristics and Mechanisms of Phosphate Adsorption onto Basic Oxygen Furnace Slag. Journal of Hazardous Materials.162: 973-980.

[11] Vohla,C., Koiv, M., Bavor, H. J., Chazarenc,F., Mander, U. 2011. Filter Materials for Phosphorus Removal from Wastewater in Treatment Wetlands- A Review. Ecological Engineering. 37: 70-89.

[12] Bowden, L. I., Jarvis, A. P., Younger, P. L., Johnson, K. L. 2009 Phosphorus Removal from Waste Waters Using Basic Oxygen Steel Slag. Environmental Science Technology. 43: 2476-2481.

[13] Zhong, B., Stanforth, R., Wu, S. Chen, J. P. 2007. Proton Interaction in Phosphate Adsorption onto Goethite. Journal of Colloidal Interfacial Science. 308: 40-48.

[14] Weng, L., Van Riemsdijk, W. H., Hiemstra, T. 2012. Factors Controlling Phosphate Interaction with Iron Oxides. Journal of Environmental Quality. 41: 628-635.

[15] Klimeski, A., Chardon, W. J., Turtola, E., Uusitola, R. 2012. Potential and Limitations of Phosphate Retention Media in Water Protection: A Process-based Review of Laboratory and Field-scale Tests. Agricultural and Food Science. 21: 206-223. 